\title{
Izrael innovációs potenciáljának alappillérei
}

Izrael napjainkban a high-tech termékek gyártásával a világ élvonalába tartozik. Ez köszönhetố annak, hogy a közel-keleti ország kormánya idóben felismerte a tudományos szektorban rejló növekedési lehetôséget, ezért a start-up vállalatok létrehozását kormányzati alapokkal támogatta. A tanulmány az izraeli innovációhoz szükséges alappilléreket veszi számba, mely a pénzügyi támogatás mellett magában foglalja az oktatást, a katonai szolgálatot, a bevándorlást és a kreativitást is.

\section{Bevezetés}

zrael, innovációs potenciáljának köszönhetően, a 21. századra már egy jól megalapozott globális hírnévvel rendelkezik. Az elismertség eléréséhez ugyanakkor hosszú út vezetett. Az állam megalapítását követően a kormány számára hamar világossá vált, hogy az arab országokkal határolt újonnan született Izraelnek a védelmi rendszerek kiépítésére kell hangsúlyt fektetnie. A high-tech védelmi iparág kialakulása és növekedése nyomán egyre nagyobb szerepet kapott a kutatás-fejlesztési szektor. A közel-keleti ország vezetői időben felismerték az említett ágazatban rejlö lehetőséget, ezért különféle módon kezdték el támogatni. Az oktatás és a pénzügyi alapok mellett a kötelező katonai szolgálat, illetve a folyamatos bevándorlás is hozzájárult Izrael sikeréhez. A high-tech termékek a védelmi iparágból fokozatosan átszivárogtak a civil szektorba, mely mára rendkívüli gazdasági növekedést biztosít a kis országnak.

\section{Az innováció szükségének felismerése}

Napjainkban az innováció ${ }^{1}$ központi szerepet képvisel a gazdaságfejlesztésben. A globális piacra való bekerülés, a versenyképesség elérése és fenntartása érdekében mindig új ötletekre van szükség. Az oktatás és a kreativitás éppen ezért kulcsfontosságú tényezők, mivel ezáltal megalapozható egy ország számára szükséges humán tőke. A tudást finanszírozva (állami, esetleg külföldi tőkével) ezután az ötletek sikeres vállalkozásokká, illetve cégekké válhatnak, melyek a gazdaságot pozitív mutatókkal gazdagítják.

Manapság számos OECD-országban a termelékenység növelése érdekében a tudományra, a technológiára és a kutatás-fejlesztésre $(\mathrm{K}+\mathrm{F})$ fektetik a legnagyobb hangsúlyt. Izrael is ezen államok közé tartozik. A helyi vezetés időben felismerte az innováció szükségességét, és az okos politikának köszönhetően útjára indulhatott a fejlődés. Az izraeli kormány a $\mathrm{K}+\mathrm{F}$ anyagi támogatásával indította be a tudomány alapú ágazatot (Moss, 2011).

Izrael létezésének első két évtizedében az ipari K + F szinte ismeretlen fogalom volt. Mindazonáltal néhány tényező, amely az információs technológia felemelkedéséhez 
nélkülözhetetlen, már a helyén volt. A három legfontosabb: a művelt munkaerő és az egyetemi kutatási ágazat folyamatos növekedése, egy kicsi, de bővülő védelmi kutatás-fejlesztési szektor és a nemzeti ideológia. Emellett az izraeli bürokrácia rugalmas szerkezete sem elhanyagolható (Breznitz, 2007, 44. o.).

A függetlenség kinyilvánítását követően az ország közel húsz évig intervenciós iparpolitikával párosult protekcionista gazdaságpolitikát követett. Ennek három fő célja, a biztonság és a regionális politika, az ipari fejlődés, valamint a magántulajdon-alapú gazdaság megteremtése. A folyamatos bevándorlás hatására új városok létesültek, amelyek magántulajdonban lévő, államilag támogatott, nagyméretü gyárak közelében kaptak helyet. A textilipar mellett fontos szerepet kapott a védelmi ipar, amely az 1960-as években, külföldi cégek és az izraeli állami szervezetek partnerségén alapuló fegyverrendszerek előállítását jelentette (Breznitz, 2007, 45-47. o.). Izrael, kis ország lévén, egyszerübb megoldásnak látta, ha más államokból szerzi be a szükséges fegyvereket, ezzel egyidejüleg azonban kiszolgáltatottá is vált, mely leginkább 1967-ben mutatkozott meg. Ekkor, legfontosabb fegyverellátója, Franciaország a hatnapos háború elött néhány nappal fegyverembargót hirdetett. A közel-keleti ország ennek hatására elhatározta, hogy saját fegyverrendszert hoz létre. Ugyanakkor érdemes megemlíteni, hogy Izraelben már az ország megalakulásakor is müködött illegális fegyverüzem. Az egyik ilyen gyárat egy kibuc mosodája, vagyis a föld alá létesítették. Emellett még afféle fegyvervadászat is jellemző volt, amelynek keretében külföldről gyüjtöttek és csempésztek lőfegyvereket az országba. Mindezen tevékenységekre azért volt szükség, mert bár a fiatal állam több országból is importált hasonló eszközöket, azok folytonossága bizonytalan volt. 1950ben például az Egyesült Államok, Nagy-Britannia és Franciaország korlátozást léptetett életbe a Közel-Keletre történő fegyvereladásokat illetően (Senor és Singer, 2012, 247-248. o.).

Franciaország embargóját követően tehát Izrael nem alapozhatott arra, hogy az európai ország helyére majd az Egyesült Államok lép, aki ekkoriban már újra védelmi eszközöket folyósított a közel-keleti országnak. 1967-ben az izraeli állam úgy határozott, hogy nagy mennyiségü erőforrást és K + F-et fordít arra, hogy a high-tech védelmi ipar gyors növekedését biztosítsa. Döntés született arról, hogy Izrael ismételten soha ne függjön teljesen idegen hatalomtól. Az említett évtől kezdve olyan kifinomult fegyverrendszerek előállítása indult útjára, mint a lokátor irányítású rakéták, tankok, harci repülőképek és hajók (Breznitz, 2007, 47. o.).

A kifinomult rendszerek használata magában foglalja az információs technológiai ágazatot is. Az első izraeli védelmi egység, amely már az 1950-es években számítógépeket fejlesztett és használt, nagy valószínüséggel a RAFAEL volt. A RAFAEL amellett, hogy információforrásként szolgált a tudomány és technológia, illetve a $\mathrm{K}+\mathrm{F}$ menedzsment számára valamint melléktermékeket fejlesztett ki, két fontos szerepet játszott. Elsőként, néhány tudós, aki az egységet alapította, ugyancsak megalkotta az 1960-as évek végén Izrael tudományos alapú iparpolitikáját. Másodszor, a RAFAEL-t az állam valamiféle inkubációs központként használta, amely „megfertőzte” a többi védelmi és civil céget, illetve szervezetet az informatikai kutatás-fejlesztés lehetőségével. Így jött létre, többek között, például az izraeli hadsereg számítógépes egysége, a MAMRAM (Breznitz, 2007, 47-48. o.).

A katonai komplexum fejlesztése mellett, az izraeli kormány a polgári ipari, tudományos és technológiai szektorra is kellö figyelmet fordított. Az 1960-as évek vége felé a fejlesztési politika a hagyományos iparágak felől az exportorientált, tőkeigényes és a high-tech ágazat irányába tolódott el. A magánvállalatok számára már ekkor elérhető volt a tőkejuttatás, mint fó támogatási forma. Emellett az állam egyes cégeknek külön $\mathrm{K}+\mathrm{F}$ támogatást is biztosított, s az egyetemeken müködö tudományos parkokat is finanszírozták (Roper, 6-7. o.). 


\section{A tudományos alapú szektor beindítása}

\section{Oktatás}

A humán tőke fontos szerepet játszott abban, hogy a kezdetben védelmi rendszerek fejlesztésére összpontosító Izrael, napjainkra a high-tech termékek gyártásáról, biotechnológiai szabadalmairól és start-up vállalkozásairól legyen nevezetes. Ehhez járultak hozzá az olyan első osztályú egyetemek is, mint például a Héber Egyetem, a Tel-avivi Egyetem vagy a Weizmann Intézet, amelyek köré innovatív cégek hálózata telepedett.

A közel-keleti országban már az állam megalapítása előtt müködtek felsőoktatási intézmények, melyekhez az idő elörehaladtával újabbak csatlakoztak. Az elsők között tartják számon az 1925-ben felavatott Jeruzsálemi Héber Egyetemet és az 1912-ben alapított, ám csak 1924-ben megnyitó Techniont, Haifában. 1934-ben újabb létesítmény látott napvilágot, melyet Izrael első államelnökéről és egyben világhírü kémikusáról Weizmann Intézetnek ${ }^{2}$ neveztek el. Napjainkra a legnagyobbá a Tel-avivi Egyetem vált, amely 1956 óta a tudományos élet egyik központja. Korai megalapításuknak köszönhetően, az 1950-es években, amikor az ország lakossága mindössze körülbelül kétmillió volt, már négy egyetemben folyt az oktatás. A tudományos képzés mellett, néhány intézet a kutatási eredmények piacra vitelében is jelentős sikereket ért el. Ezek egyike a Weizmann Intézet által létrehozott Jeda Intézet, amely mind a mai napig az orvostechnológiai termékek és cégek születéséhez járul hozzá. Hasonló a Jedához a Jisszum, amely a Héber Egyetem technológiatranszfer cége. Utóbbi meghatározó szerepét bizonyítja, hogy kutatási eredményeit olyan nagy multinacionális cégek vásárolják fel, mint például az IBM vagy az Intel (Senor és Singer, 2012, 284-286. o.).

A felsőoktatási intézmények korai kialakítása jelentősen hozzájárult Izrael tudományos szektorának a fejlődéséhez. Az oktatás nevezhető az egyik alappillérnek, mely nemcsak a kutatás-fejlesztéshez biztosított bázist, hanem a folyamatosan érkező bevándorlók tömegeinek is előrelépési lehetőséget. Mindazonáltal az új ágazat beindításához finanszírozásra is szükség volt, mely életre hívta a második pillér, a Tudományügy Megbízott Hivatalának létrejöttét.

\section{A Tudományügy Megbízott Hivatala}

A tudományos szektor pénzügyi támogatása 1965-ben került elötérbe, amikor Tolkowsky és Galil ${ }^{3}$ aktiválta azt a folyamatot, amely végül Izrael első tudományos és technológiai iparpolitikai és fejlesztési ügynökségéhez vezetett. Mivel állami támogatás nélkül az iparág jövője elképzelhetetlen volt, kitalálták, hogy egy kisebb ipari $\mathrm{K}+\mathrm{F}$ támogatási programot kellene létrehozni. Az ötletet a Kereskedelmi és Ipari Minisztériumnak prezentálták, s azzal érveltek, hogy a tudomány alapú iparág rendkívül fontos az ország gazdasági jövője szempontjából. A minisztérium illetékese, Dovrat elfogadta a kezdeményezést, és megalkotott egy részmunkaidős pozíciót, nevezetesen a vezető tudóst, aki kiértékeli az új termékek támogatási indítványait. Így jöhetett létre a Tudományügy Megbízott Hivatalának (TMH) elődje (Breznitz, 2007, 49-50. o.).

A TMH történetének következő állomása 1966-ra tehető, amikor Lévi Eskól miniszterelnök összehívott egy bizottságot. Eskól úgy vélte, hogy az éppen gazdasági recesszióban lévő országnak változtatnia kell ipari politikáján, és a növekedés egyik forrásaként a tudományt jelölte meg. A Katchalski Bizottság több feladatot is kapott. Egyrészt, felül kellett vizsgálnia a tizennégy nyilvános civil kutatóintézetet és szerkezetátalakításukat, illetve vezetésüket illetően ajánlásokat kellett tennie. Másrészt, a $\mathrm{K}+\mathrm{F}$ hatóság munkáját is elemeznie kellett. A bizottság végül két évvel később, 1968-ban nyújtotta be jelentését és ajánlásait Eskól miniszterelnöknek. A testület kutatásának két területen lett hosszú 
távú eredménye. Elsőként a bizottság javasolta a vezető tudós számára egy hivatalos pozíció létrehozását az összes fő minisztériumban. Másodszor a nemzet, gazdasági sikereinek feltételét a tudomány gyakorlati technológiává alakításában látta. Emiatt az izraeli államot a $\mathrm{K}+\mathrm{F}$ tevékenység ösztönzésére szorgalmazta. Ugyanakkor a Tudományügy Megbízott Hivatalának kialakítása még tovább váratott magára. 1968 és 1974 között a TMH a már fennálló részmunkaidős formában folytatta tevékenységét. A szervezet gyakorlatilag inaktív volt, mivel az ipari $\mathrm{K}+\mathrm{F}$-re szánt költségvetése nagy részét az állami kutatóintézetek emésztették fel, s a bürokrácia miatt az új javaslatokkal előálló vállalatoknak akár két évnél is többet kellett várniuk a válaszra. A változás végül 1974-ben következett be, amikor a kereskedelmi és ipari miniszter Yitzhak Yaakovot kinevezte az első főállású vezető tudósnak, mellyel egyidejüleg létrejött a már sokat említett Tudományügy Megbízott Hivatala. Yaakov elképzeléseinek megvalósításához szabad kezet, megfelelő anyagi forrást és politikai támogatást is kapott. Yaakov, új pozícióját elfoglalva, négy irányban haladt elöre (Breznitz, 2007, 51-54. o.). Egyrészt megfogalmazta a TMH célkitüzéseit, mely nem más, mint Izrael gazdasági növekedésének elősegítése, azáltal hogy pénzügyi támogatást biztosítva serkenti a technológiai innovációt és a vállalkozásokat, kihasználva ezzel az ország tudományos kapacitását (Friedfeld és Metoudi, 2015). Napjainkban a TMH ugyanezen irányvonal mentén halad.

Yaakov elképzelése szerint a magáncégek optimális ügynökök, nemcsak a K + F-re nézve, hanem abból a szempontból is, amikor dönteni kell, milyen projekteket vállaljanak, és milyen technológiákat fejlesszenek. Éppen ezért az állam szerepét az egyéni vállalkozók motiválására szükítette. A TMH egy központi kutatás-fejlesztési alapból visszafizetendő hitelként 50 százalékos hozzájárulást nyújtott a hozzá benyújtott és általa jóváhagyott projektjavaslatok $\mathrm{K}+\mathrm{F}$ költségeihez. Ezzel párhuzamosan a bürokrácia is leegyszerüsödött, így egy cég két év helyett akár már tíz nap alatt szerződést köthetett a TMH-val. A célkitüzések megismerése után, másodjára a hivatal erőteljesen csökkentette az állami kutatói intézmények finanszírozását, ugyanakkor a magánvállalkozásokkal történő közös munka esetén garantálta a támogatást. Harmadszor, 1974-ben a közel-keleti ország már elérte azt a felső határt, amelyet a Világbank még fejlődő államnak nevez. Yaakov ekkor lehívta az utolsó világbanki hitelt, amelyet olyan programra fordított, mely lehetővé tette a TMH-nak legfeljebb 8 projekt 80 százalékos támogatását. Ezenfelül, ebben az időben jött létre az Egyesült Államok és Izrael között az a megállapodás, amely megalkotta a két ország cégeinek az úgynevezett BIRD alapot. Végül, Yaakov a Tudományügy Megbízott Hivatalát egy aktív, iparággal foglalkozó ügynökséggé alakította, amely 1974-re már 70 millió lírát érö javaslatok összességét fogadta el (Breznitz, 2007, 54-55. о.).

Az 1970-es évekre ugyancsak jellemző, hogy Izrael nyitottabbá vált a kereskedelem és a külföldi beruházás iránt. 1975-ben szabadkereskedelmi megállapodást kötött az Európai Közösséggel valamint kétoldalú szerződést írt alá az Egyesült Államokkal - BIRD alap - és Németországgal - GIF - ezáltal közös K + F forrásokat létrehozva. Ugyanakkor, a külföldi befektetések bevonzása, különösen az ország perifériás területeire, ekkor még többnyire sikertelennek bizonyultak. Ennek ellenére gyors strukturális változás zajlott a belföldi tulajdonú szektorban: a hadsereg kiépítése és fejlesztése folytatódott, és így az azzal kapcsolatos polgári elektronikai, illetve légi ipar is bővült. Ezt alátámasztja, hogy 1968 és 1983 között a high-tech ipar a korábbi 6 százalékról 24 százalékra növelte részesedését a termelésben, és 5 százalékról 28 százalékra az exportot illetően (Roper, 7. o.).

Mindazonáltal fontos megjegyezni, hogy a TMH tevékenysége a kockázati tőke megjelenéséig nem bizonyult túlzottan sikeresnek. Az ösztöndíjak, melyeket a hivatal folyósított, nem voltak elegendőek a sokszor értékes terméket gyártó start-upok számára. Tőkeutánpótlás hiányában a cégek nagy része nem tudta piacra vinni árucikkeit, melynek következtében csődöt mondtak (Senor és Singer, 2012, 228. o.). Mindez részben Yaa- 
kov távozásával is magyarázható, mivel ezután a TMH veszített korábbi helyzetéből. A törvény által meg nem határozott hivatalnak költségvetési harcokat kellett vívnia. Ez az 1980-as évek közepéig ment így, amikor döntés született a védelmi K + F-re fordított támogatások csökkentéséről. ${ }^{4} \mathrm{~A}$ fokozódó gazdasági válság is hozzájárult ahhoz, hogy a Tudományügy Megbízott Hivatala átalakuljon, és új programokat irányozzon elő, amely ebben az időszakban két erős kereskedelmi és ipari miniszter segítségét is élvezte, nevezetesen Ariel Sharonét és Moshe Nissimét. Az 1984-ben jóváhagyott K + F törvény és az 1985-ben önálló iparágként elismert szoftver szektor mérföldkövet jelentett a tudományos és technológiai iparpolitikában, valamint a csúcstechnológiai iparág élvonalba kerülésében. Az új jogszabály a TMH-t Izrael hivatalos tudományos és technológiai ipari ügynökségévé tette, s így a hivatal és a BIRD is kiterjeszthette tevékenységét. A K + F törvény az 1990-es évek közepéig engedélyezte, hogy a TMH az összes ,átvilágításon” átment projektet finanszírozza. Ez lehetőséget adott a hivatalnak, hogy létrehozza és fenntartsa az iparág $\mathrm{K}+\mathrm{F}$ iránti igényét, mely által az egyéni IT vállalkozók is egyre gyakoribbak, aktívabbak és sikeresebbek lettek (Breznitz, 2007, 63-64. o.).

\section{BIRD, a Kétnemzeti Ipari Kutatási és Fejlesztési Alap}

Az izraeli kockázati tőke megjelenése előtt a Tudományügy Megbízott Hivatala mellett a BIRD ${ }^{5}$ szerepe is kiemelkedő volt. Az 1990-es években kezdődő nagy high-tech forradalom előtt az említett két szervezet biztosított tőkét a start-upoknak. Éppen ezért úgy vélem, a tudományos alapú szektor beindítását tárgyalva fontos szót ejteni a BIRD születésének körülményeiről is.

Ahogy azt korábban említettem, a Kétnemzeti Ipari Kutatási és Fejlesztési Alap az Egyesült Államok és Izrael között kötött kétoldalú megállapodás. Az 1976-ban aláírt szerződést követően két év telt el, mire az alap megkezdte müködését. A BIRD célja, a két ország vállalkozásai közötti együttmüködés ösztönzése volt, vagyis hogy közösen dolgozzanak ki és adjanak el új termékeket (Breznitz, 2007, 57-58. o.). 1978-ban Ed Mlavsky vette át a 110 millió dolláros tőkével létrehozott alap vezérigazgatói székét, mely ekkortól vált aktív szervezetté. A BIRD ötszázezer és egymillió dollár közötti összeggel támogatta az amerikaiizraeli vegyesvállalatokat. Mindehhez Mlavsky és dolgozói munkája is hozzájárult azzal, hogy a technológiai tőkével rendelkező izraeli vállalatoknak megfelelő párt keresett az amerikai piacon. Az amerikai cégek szerepe a reklámozásban és a termék forgalmazásában rejlett. Elmondható, hogy a Kétnemzeti Ipari Kutatási és Fejlesztési Alap jó kapcsolódási lehetőséget biztosított a tengerentúli piachoz, melyet mi sem bizonyít jobban, hogy 1992-re a New York-i tőzsdén bejegyzett izraeli cégek majdnem 60 százaléka BIRD támogatásban részesült (Senor és Singer, 2012, 228-230. o.).

Mindemellett a Kétnemzeti Alap még egy szempontból jelentősnek bizonyult. Az 1980-as évektől kezdve Izraelbe vonzotta a multinacionális cégeket, amelyek K + F központokat nyitottak az országban. Mindez lehetséges volt, mivel a közel-keleti állam alacsony kockázatú, barátságos környezetet biztosított a kutatás-fejlesztést illetően, valamint a szervezet képes volt aktívan meggyőzni a nagy cégeket, hogy Izraelbe telepedjenek. Az aktív meggyőzés hátterében a pénzügyi finanszírozás rejlik, amelyet nem csupán a BIRD, hanem a TMH is képviselt. A Tudományügy Megbízott Hivatala elismerte az Izraelben a $\mathrm{K}+\mathrm{F}$ céljából nyilvántartott multinacionális cégek leányvállalatait, így ezáltal ők is élvezhették a Kétnemzeti Alap és a TMH támogatását. Így a külföldi cégek kedvező költségekkel kezdhettek $\mathrm{K}+\mathrm{F}$ tevékenységet a Közel-Keleten. A TMH-hoz hasonlóan, a BIRD is visszatérítendö ösztöndíjakat osztott szét, amelyet a termék értékesítésekor 5 százalékos jogdíj ellenében szerez vissza, ám ez az összeg az eredeti támogatás legfeljebb 150 százaléka lehet (Breznitz, 2007, 59. o.). 
A kormány okos politikája lévén létrejött két programnak köszönhetően, a hagyományos iparágakkal és a mezőgazdasággal szemben, az IT ipar az elveszett évtized évei alatt is növekedést produkált. Így 1988-ra Izrael ipari exportjának 59 százaléka a csúcstechnológiai termékekből származott. A sikerek ellenére azonban az említett szektor sem úszta meg sértetlenül a gazdasági válságot. Az 1970-es években a high-tech ipar gyarapodása lassú volt, mivel a TMH nehezen tudta a teljes évi költségvetését kiutalni, így nem sok új cég alakulhatott (Breznitz, 2007, 62. o.). Az újabb pozitív fordulatot majd csak az 1990-es évek eleje hozza el, amikor a nagyszámú új bevándorlónak köszönhetően új programokra lesz szükség, melyek egy része a TMH égisze alatt valósul meg.

\section{A katonaság hatása a tudományos szektorra}

A tudományos szektor harmadik alappilléreként a katonaság nevezhető meg. A hadsereg szerepe nem csupán az új eszközök, fegyverrendszerek kifejlesztése miatt, hanem a katonák képességeinek formálását illetően is mind a mai napig jelentős. Ennek köszönhetően, Izraelben a szolgálati idő letelte után sokan válnak vállalkozóvá, és indítanak saját start-up céget.

A közel-keleti ország high-tech történetének gyökerét az 1948-ban létrehozott, fejlett katonai felszereléseket gyártó Izraeli Védelmi Erök tudományos alakulata adja. Következésképp a katonai-ipari komplexum már régóta szolgál afféle gépezetként, amely a tudományos ismereteket a hadseregböl a civil szektorba exportálja. Ennek alapja a minden izraeli zsidónak - férfiak és nők egyaránt - kötelező katonai szolgálat (Sharaby, 2002). A hagyományos egységek mellett a sereg csúcstechnológiai alakulatokat is felállított, ahol számítógéphez értő sorkatonákat folyamatosan arra kérnek, hogy innovatív ötleteket dolgozzanak ki olyan területeken, mint például a számítógép-biztonság, a kriptográfia, a kommunikáció és az elektronikus hadviselés. Így tehát a katonaság lehetővé teszi a fiataloknak, hogy technológiai ismereteket szerezzenek, és nagy technológiai projektekben vegyenek részt (Moskvitch, 2011).

Az egyik különleges alakulat a 8200-as egység, melynek létezésére csupán körülbelül egy évtizede derült fény, $s$ története is csak részlegesen ismert. ${ }^{6}$ Mivel Izrael egy idő után nem akarta a másoktól való függést tovább kockáztatni, a 8200 lett az ország egyik belső $\mathrm{K}+\mathrm{F}$ központja. Bár a Moszad kémügynökség ismertebb, a hírszerzés 90 százaléka a 8200-as egységtől érkezik. Az alakulat egy jól felépített rendszer alapján müködik, amely azt veszi fel tagnak, akit csak akar. Ugyanakkor a lehetséges jelöltek azonosítása után szigorú interjúkat, teszteket és órákat kell teljesíteni, amelyek akár hat hónapnál tovább is eltarthatnak. Figyelemfelkeltő, hogy a felvételi interjúkat nem magas rangú tisztek, hanem az egység fiatal katonái vezetik, akik a saját munkájukra alkalmas embereket keresnek. A matematika, a számítógépes és az idegen nyelvi ismeretek pluszt jelentenek, ugyanakkor a különleges alakulat olyan képességekkel rendelkező katonákat választ meg tagjainak, akik gyorsan tanulnak, alkalmazkodnak a változáshoz, sikeresen dolgoznak csapatban, és képesek a lehetetlennek tünő helyzeteket kezelni. A minden évben újonnan beáramló intelligens és motivált fiatalok mindig újabb szempontból vizsgálják az egyes problémákat, és a start-up mentalitás áthatja az egész egységet. A hajtóerő alapja a találékonyság, ugyanis senki nem mondja meg a katonáknak, hogy pontosan mit kell csinálni, hanem egy problémával szembesülve szoros határidőn belül nekik kell kitalálni egy megoldást. Ezen feladat építi a feltaláló és vállalkozói képességet. Akárcsak a hadsereg hagyományos egységeinél, a 8200 öregdiákjainak is tartalékosként kell szolgálniuk, mely negyvenéves korukig évente legfeljebb három hetet jelent. Ennek előnye, hogy a veteránok évtizedek múltán is betekintést nyernek a legújabb technológiai fejlesztésekbe (Behar, 2016). 
Egy másik, hasonlóan egyedülálló, megszürt egység a Talpiot. A katonák kiválasztása ehhez az alakulathoz is már a középiskolákban kezdődik, és csupán a legtehetségesebb diákok nyernek felvételt a Talpiot-programba. Az Izraeli Védelmi Erők (IDF) legnagyobb ágainak, a technológiai és katonai igények megismerése mellett azonban nagyobb hangsúly kap a küldetéstudattal rendelkező és problémamegoldásra képes vezetők képzése. A feladatok ezért sokrétüek, melyek a konferenciaszervezéstől a telekommunikációs hálózat feltöréséig is terjedhetnek. A program a Mafat, vagyis az IDF belső kutatási és fejlesztési ága alatt fut, s a kihívást sikeresen teljesíto „Talpionok” nemcsak a hadseregben, hanem a civil életben is nagy tekintélyre tesznek szert. Ezt alátámasztja, hogy a program elvégzése után többen akadémikusok vagy globális vállalatok alapítói lettek (Senor és Singer, 2012, 112-115. o.).

A két különleges egység példáján keresztül megállapítható, hogy Izraelben nagy szerepe van a hadseregnek. Az ország védelme mellett a katonák szolgálati idejük alatt sok olyan képességet elsajátítanak, amire a későbbiekben szükségük lehet. Ami az állam innovációs potenciáljához hozzájárul, az az, hogy a fiatalok a seregben megtanulnak fegyelmezettek lenni, önállóan döntéseket hozni, és ha a szükség úgy kívánja, saját találékonyságukat is kifejleszthetik. Mindemellett van még egy fontos tényezö, amelyröl nem szabad elfeledkezni: a kapcsolati háló.

Izraelben, kis ország lévén, egy jól működő kapcsolati rendszer jött létre. Ehhez a kötelező és tartalékos katonai szolgálat is hozzájárult. A hadseregben kialakult sze-

A két különleges egység példáján keresztül megállapitható, hogy Izraelben nagy szerepe van a hadseregnek. Az ország védelme mellett a katonák szolgálati idejük alatt sok olyan képességet elsajátítanak, amire a késóbbiekben szükségük lehet. Ami az állam innovációs potenciáljához hozzájárul, az az, hogy a fiatalok a seregben megtanulnak fegyelmezettek lenni, önállóan döntéseket hozni, és ha a szükség úgy kivánja, saját találékonyságukat is kifejleszthetik. Mindemellett van még egy fontos tényezó, amelyról nem szabad elfeledkezni: a kapcsolati háló. mélyes kapcsolatok a leszereléssel egy időben nem szünnek meg, mivel a tartalékos rendszer biztosítja az évenkénti találkozókat. A katonaság így kiváló helyszín a különböző üzleti szférából érkező vállalkozóknak, hogy megismerjék egymást. A hadgyakorlatok alatt új üzleti kapcsolatok alakulnak ki, amelyek végső soron az ország innovációjának mozgatórugói lehetnek (Senor és Singer, 2012, 119. o.).

Következésképpen megállapítható, hogy a katonaság több szempontból is kiemelkedő szerepet képvisel Izraelben. Az ország nemzetközileg is versenyképes hadiiparának felemelkedése döntő motorjává vált az exportorientált növekedésnek. Az arab szomszédok elleni folyamatos hadviselés miatt létrehozott védelmi ipar a világ egyik legnagyobb fegyverexportőrévé tette a kormány által támogatott katonai-ipari komplexumot. A védelmi szektor tovagyürüző hatása elérte a kereskedelmi ágazatokat, és elősegítette az 1990-es évek csúcstechnológiai forradalmát (Sharaby, 2002). 


\section{A humán tőke folyamatos utánpótlása: zsidó bevándorlás}

Izrael innovációs potenciáljának létezik még egy fontos eleme, amely az alappillérek közé sorolható. A zsidó bevándorlás, mely mind a mai napig végigkíséri a 68 éves ország történetét, nagy hatással bírt az állam megalapítására és a képzett munkaerő folyamatos utánpótlására. Különösen meghatározó volt az 1990-es években beáramló magasan iskolázott embertömeg, amely a gazdaság s egyben a start-upok motorjává vált.

1948-ban Izrael állam megalapításakor a népességszám 806000 fő volt. Ez a szám már a megalakulást követő két évben megduplázódott, majd a következő hét évben 30 százalékkal növekedett. Gyakorlatilag három izraeli közül kettő új bevándorló volt (Senor és Singer, 2012, 41. és 182. o.). Már 1948 második felében nagyjából százezren érkeztek, így az év végére a körülbelül 900000 lakosból 750000 volt zsidó. 1949-ben további 240 000, 1950-ben 170 000, 1951-ben pedig 175000 fó vándorolt be az országba. A folyamat, még ha néha lassuló tendenciát is mutatott, folytonos volt. 1972 végén a népességszám elérte a 3,2 milliót, melynek csaknem 85 százaléka volt zsidó származású. A közel-keleti állam létrejöttekor a lakosság iskolai végzettsége is kiemelkedő volt. Ez elsősorban a magas szintű oktatásban részesült bevándorlóknak köszönhető, akik főleg az 1930-as években jöttek Németországból. Ugyanakkor mindez már nem volt igaz az 1948 után érkezettekre. Ennek egyik magyarázata, hogy eleinte azon keleti-európai zsidók költöztek az új országba, akiknek sikerült túlélni a holokausztot. A főleg koncentrációs táborokból szabadultaknak fogságuk idején nem volt lehetőségük hozzáférni az oktatáshoz. A másik tényező, az 1949-től Ázsiából és Afrikából kezdődő tömeges bevándorlás volt. Az elsődlegesen Irakból, Jemenből és Marokkóból útjára indult polgárok képzettségi szintje lényegesen alacsonyabb volt, mint az európai társaiké. A helyzet javítása érdekében - miként azt a korábbi fejezetben már részletesen elemeztem - az oktatási rendszer kiemelkedő fontosságúvá vált Izraelben. Fontos megjegyezni, hogy az első néhány évben érkező bevándorlóknak a hivatásukkal összefüggő szakértelmük sem volt megfelelő az izraeli kereslet számára. Legtöbbjük kereskedő, hivatalnok, kézmüves vagy iparos volt, ugyanakkor a közel-keleti ország a mezőgazdaság, az ipar, illetve az építőipar területére keresett munkaerőt. Néhány esetben a nyelvtudás is akadályt jelentett. Például akik korábban közigazgatásban dolgoztak, a nyelv ismeretének hiányában új lakóhelyükön nem tudtak ugyanezen pozícióban elhelyezkedni. Mindezek következtében a legtöbben megváltoztatták foglalkozásukat, s ezáltal egy szakképzetlen munkásréteget hoztak létre (Michaely, 1975).

Bár a bevándorlás szempontjából egy olyan állam, amely szinte állandóan háborúban áll szomszédjaival, ahol férfiaknak és nőknek egyaránt kötelező a katonai szolgálat, és állandó a terrorfenyegetettség, általában nem célország, ez Izrael esetében megkérdőjelezendö. A folyamat ugyanis a jisuv óta permanens.

A napjainkban nagyjából 8 milliós népességgel rendelkező államban a kezdetek óta több mint 3 millió új lakos telepedett le. Ez a szám magában foglalja a korábbi Szovjetunióban élő több mint 1 millió főt, a körülbelül 150000 észak-amerikait, a 80000 franciát, a 70000 argentínait, a 35000 Egyesült Királyságból és a 20000 Dél-Afrikából útjára indult polgárt (Friedfeld és Metoudi, 2015).

A spontán bevándorlás mellett az izraeli kormány is segítette a „külföldön ragadt” zsidók „hazatérését”. Kiváló példa erre az etióp zsidók esete. Az 1984-ben véghezvitt Mózes- hadmüvelet több mint nyolcezer etióp zsidót menekített át Izraelbe, akik már másnap megkapták az állampolgárságot. Közéjük tartozott Slomo Molla, aki barátaival gyalog indult Etiópiából a Szentföldre. Miután Szudánban őrizetbe vették, csak az említett repülögépes akciónak köszönhette, hogy elérte célját. Habár az agrárközösségböl érkező etiópok nagy része analfabéta volt, Molla később politikus lett, s parlamenti képviselőként bejutott a Knesszetbe. A siker elkönyvelése után a kormány hét év elteltével 
újabb bevetést indított. A Salamon hadmüvelet keretében 36 óra leforgása alatt mintegy 14500 etiópot szállítottak a közel-keleti országba. Mindazonáltal meg kell jegyezni, hogy az etióp bevándorlás - az orosz bevándorlással ellentétben - nem tett jót az izraeli gazdaságnak. Integrációjuk lassú volt, s legtöbbjük állami segélyekböl élt (Senor és Singer, 2012, 177-179. о.).

Az 1990-es évek, a bevándorlás és a gazdaság szempontjából is mérföldkőnek bizonyult. Mindez a korábbi Szovjetunióból beáramló embertömegnek köszönhető. Az első három évben körülbelül 450 000-en telepedtek le, akiknek a 40 százaléka diplomával rendelkezett. Nagyobb távlatban tekintve, az 1989 és 1995 között érkező 750000 polgárból közel 11000 volt tudós és kutató mérnök, amely akkor a lakosság 1,5 százalékát tette ki. Ezáltal, Izrael tudományos és mérnöki közössége hat év alatt 15 000-röl 26 000-re bővült. Bár képzettek voltak, mindannyian nem tudtak képesítésüknek megfelelö munkát találni. Ennek ellenére nagy hatást gyakoroltak az izraeli tudományos világra és az iparra (Roper, 8-9. o.). A jó időben érkezett orosz zsidók összevetve a védelmi iparból elbocsájtott mérnökökkel együtt újabb kihívást jelentettek a kormánynak. Az új lakók letelepítésének érdekében a közel-keleti államot az Egyesült Államok 10 milliárd dollárt érő kötvényekkel segítette (Breznitz, 2007, 77. o.). Az oroszok Haifában alakították ki a legnagyobb közösséget, ahol 21000 bevándorlóból ők 15 000-et tesznek ki. Ezután következik Bet Yam és Ashdod, s Tel-Aviv csupán a negyedik helyet foglalja el 8800-as orosz zsidó lélekszámával ${ }^{7}$ (Pohoryles, 2016). Mindemellett az új tudósok és technikusok beáramlása számos fejlesztést vont maga után, mind a tudományos, mind pedig a kereskedelmi szektorban. Az egyik legjelentősebb az 1991-ben bevezetett technológiai inkubátorprogram volt.

\section{Szükségszerüség és az izraeli hücpe}

A tudományos szektor sikeréhez és Izrael innovációs „nagyhatalommá” válásához a felsorolt alappillérek mellett fontos még néhány kevésbé fajsúlyosnak tűnő tényezőt is figyelembe venni. Ezek közé tartozik például a találékonyság és az izraeli magatartás. Feltehető ugyanis a következő kérdés: Hogyan képes a kis területtel rendelkező Izrael ellenséges környezetben folyamatos növekedést produkálni? A válasz nagy része a kultúrában rejlik, bár kétségtelen, hogy az okos politika is hozzájárult a „győzelemhez”.

Az első tényező tehát a hücpe ${ }^{8}$ vagyis az izraeliek sajátos magatartása. Ebben a közvetlen stílusban benne van minden, ami az innovációhoz szükséges. A hücpe jelenti azt, hogy a munkavállalók megkérdőjelezik a munkaadókat és azt is, hogy a közalkalmazottak kijavítják a „felsőbbrendü” minisztereket. Ez az izraeliek számára elfogadott, ám kívülállóként szokatlannak tünő norma abban is megmutatkozik, hogy a közel-keleti országban bármilyen pozícióban levő személyt a becenevükön szólítanak. Ez a fajta magatartás és közvetlenség valószínűleg a kulturális toleranciából ered. A helyi befektetők nagy része ugyanis úgy gondolja, hogy a valódi innováció elérése érdekében a kudarcokat is el kell viselni. Az úgynevezett értéksemleges látásmód kialakítása már a hadseregben elkezdődik, ahol egy kiváló teljesítményt nem ünnepelnek meg, ugyanakkor a rossz miatt sem küldenek haza senkit (Senor és Singer, 2012, 60-61. o.).

A második tényező a szükségszerüség. Az izraeli innovatív technológiák fejlődésének közös pontja, hogy mindegyik céget a szükségszerüség hajtja. A zsidó kultúra, mely kreativitásáról jól ismert, felismerte, hogy globálisan kell gondolkodnia. Mivel a kis országot szomszédjai már születésekor megtámadták, Izrael nem tudott az öt körülvevő piacokra termelni. Éppen e miatt a kényszerhelyzet miatt vált találékonnyá. Amellett, hogy olyan technológiai újításokat fejlesztett ki, melyekre saját magának is szüksége volt, elkezdett globálisan gondolkodni, hogy hol és milyen termékekre lehet igény. Igy kerültek be a latin-amerikai, az ázsiai és az afrikai piacra is. 
Érdemes megemlíteni például a Zsidó Szív Afrikáért elnevezésű NGO-t, amelynek célja, hogy az izraeli technológia segítségével fenntartható fejlődést biztosításon a vidéki afrikai falvak iskolái, árvaházai és klinikái számára. A szervezetnek napelemes technológia telepítésével sikerült is távoli afrikai falvakba villamosenergia-infrastruktúrát kiépítenie. Ezenkívül, a napelemek hozzájárulnak a tiszta víz eléréséhez is, ugyanis az általuk hajtott szivattyúk képesek naponta több liter vizet rendelkezésre bocsájtani (Uda$\sin , 2012)$.

Az izraeliek tehát vállalkozóknak születnek, mert nincs más választásuk, mint kockáztatni és különböző vállalkozásokat indítani. Emellett van még egy kulcsfontosságú tényező, amely gondoskodik az innovációs sikerről. A legtöbb eredményes izraeli cégtulajdonos nagyobb sikereket és globális elismerést akkor érhet el, ha egyesül vagy beolvad egy nagyobb - legtöbbször külföldi - vállalatba, illetve ha a tőzsdét választja. Ezért nem ritka, hogy egy-egy vállalkozó élete során több start-upot is létrehoz, mire pozitív eredményeket könyvelhet el (Friedfeld és Metoudi, 2015). Mivel ezen intézmények alapítása nem korhoz kötött, az izraeliek bátorságát a következő példa is alátámasztja. Itay Pincas mindössze 14 éves, ugyanakkor már két start-upot tudhat magáénak. Az elsőt, nevezetesen a Joy2dayt, amely mobil alkalmazásokat fejleszt, 13 évesen hozta létre. A másik, a Teencrew pedig egy marketingtanácsadó, azon vállalkozásokat és hirdetőket célozza meg, akik termékeikkel a tizenévesek felé orientálódnak. Pincasnak, aki mindig érdeklődött a technológia iránt, egy, az izraeli vállalkozókra jellemző jövőterve van. Először a 8200-as elit egységénél szeretne szolgálni a hadseregben, aztán egy időre a Szilícium-völgybe költözni, majd miután néhány cégnél tapasztalatot szerzett, saját vállalkozást alapítana, vagy egy olyan nagy high-tech intézménynél dolgozna, mint az Apple, a Google vagy a Facebook (Maltz, 2016).

\section{Összegzés}

Napjaink izraeli gazdaságát tekintve - ahol start-upok sokasága működik - megállapítható, hogy az ország időben felismerte a tudományos szektorban rejlő potenciált. Az okos politikának köszönhetően létrejöttek az ágazat növekedéséhez szükséges alappillérek. Ezen alapfeltételek megteremtését követően az izraeli kreativitás zöld utat kapott, és az ország mára az innováció közel-keleti központjává emelkedett. A kutatás-fejlesztésre fordított tőke tehát előnyösnek bizonyult, mivel Izrael a védelmi rendszerek kialakításától eljutott a mindennapi életet megkönnyítő csúcstechnológiai eszközök fejlesztéséig.

\section{Irodalomjegyzék}

Behar, Richard (2016): Inside Israel's secret Startup machine.

http://www.forbes.com/sites/richardbehar/2016/05/ 11/inside-israels-secret-startup-machine/\#649e277 d157d

Breznitz, Dan (2007): Innovation and the State. Yale University Press, New Haven.

Dan Senor és Saul Singer (2012): Startra kész nemzet. Patmos records, Budapest.

Friedfeld, Lionel és Metoudi, Philippe (2015): Israel and China: From Silk Road to Innovation Highway. https://books.google.hu/books?id=JalrCgAAQBAJ\& pg=PT87\&lpg $=$ PT $87 \& d q=$ israel $\% 20$ innovation $\% 20$ key\&source $=$ bl\&ots $=$ PYMEwhA2ue $\&$ sig $=$ K56jaY $5 \mathrm{I}$ AdVap-6MESw75NXGGMM\&hl=hu\&sa=X\&ved $=0$ ahUKEwjq-uCR8uvMA hUQkR QKHYCTBwsQ6 A EIXDAI $\# \mathrm{v}=$ onepage $\& \mathrm{q}=$ israel $\% 20$ innovation $\% 20$ key\&f=false

Maltz, Judy (2016): Startup Nation, Jr.: This 14-yearold Israeli has already started two businesses. http://www.haaretz.com/israel-news/business/. premium-1.713112

Michaely, Michael (1975): Foreign Trade Regimes and Economic Development: Israel.

http://www.nber.org/chapters/c4556.pdf 
Moskvitch, Katia (2011): How Israel turned itself into a high-tech hub.

http://www.bbc.com/news/business-15797257

Moss, Iian (2011): Start-up nation: An innovation story.

http://www.oecdobserver.org/news/fullstory.php/ aid/3546/Start-up_nation:_An_innovation_story.html

Pohoryles, Yaniv (2016): Immigration to Israel - but whither in Israel?

http://www.ynetnews.com/articles/0,7340,L-4798543, 00.html
Roper, Stephen (2000): Innovation policy in Israel, Ireland and the UK - An evolutionary perspective. Working Paper Series NO. 47.

Sharaby, Linda (2002): Israel's economic growth: Success without security.

http://www.rubincenter.org/2002/09/sharaby-200209-03/

Udasin, Sharon (2012): Jewish Heart for Africa finishes 58th solar project.

http://www.jpost.com/Jewish-World/JewishFeatures/Jewish-Heart-for-Africa-finishes-58thsolar-project

\section{Jegyzetek}

${ }^{1}$ Eredete az in-novare latin kifejezésre vezethető viszsza, melynek jelentése: újulásban. Erre utal a napjainkban használatos innováció szó, amely egy újítás létrehozására, egy új ötlet megvalósulására utal.

${ }^{2}$ A Chaim Weizmann professzorról elnevezett Intézet ma is Izrael első számú és a világ egyik vezető kutatóintézete.

${ }^{3}$ Tolkowsky, korábbi légierő parancsnok, az 1960-as évek elején csatlakozott a Discount Investmenthez, az egyetlen olyan befektetési és pénzügyi társasághoz, amely szívesen fektetett be az IT iparba. Tolkowsky 1961-ben találkozott Galillal, az Elron csoport alapítójával, amely az első és több éven át a legfontosabb központja volt az új technológián alapuló informatikai cégeknek. Az 1960-as és 1970-es években a két cég lett a fö forrás az új technológián alapuló cégek számára.
${ }^{4}$ Fontos megjegyezni, hogy bár a védelmi ipar szektorának támogatása csökkent, a hadsereg nem mérsékelte a kutatás-fejlesztéssel kapcsolatos tevékenységét.

${ }^{5}$ Binational Industrial Research and Development, magyarul: Kétnemzeti Ipari Kutatási és Fejlesztési Alap.

${ }^{6} \mathrm{Az}$ egység eredete valószínűleg a brit mandátumi időkre nyúlik vissza, ám az idő előrehaladtával többször is nevet változtatva végezte tevékenységét.

${ }^{7}$ A Szovjetunióból származó zsidók többezres létszámban több városban szóródtak szét, itt csak a listavezetőket említem.

${ }^{8}$ Jelentése nehezen megfogalmazható, Leo Roston definiálásában: „epés, pimasz magabiztosság, arcátlan, vakmerő mersz, arroganciával párosult elbizakodottság". 